\title{
On the Origin of Formation of the Intelligentsia as a Subject of Social Action In Russia
}

\author{
Galina V. Logunova* \\ Irkutsk State University \\ 1 Karl Marx Str., Irkutsk, 664003, Russia
}

Received 13.01.2015, received in revised form 22.02.2015, accepted 22.03.2015

The article focuses on the problems of formation of the intelligentsia as a subject of social action. The author comes to the conclusion that the roots of the intelligentsia in Russia dates back to the first Russian princes who strove to form Russian statehood and Russian spiritual tradition, serving a super personal idea and the interests of universal prosperity.

Keywords: intelligentsia, intelligence, Kievan Rus', Russian princes.

Research area: history.

The problem of the intelligentsia is one of the issues which have been in the epicenter of Russian social idea for almost a century. There is hardly a philosopher, sociologist or cultural studies scholar in Russia, who hasn't addressed the issues of nature of the intelligentsia, its historic mission, and its role in the formation of national identity.

The intelligentsia is an integral part of any society, growing together with it and consisting of people who are professionally involved in the regulation of a human's behavior in the system of social production. In recent opinion the intelligentsia has existed at all times, throughout the history of mankind. Therefore, one can speak of the intelligentsia of the Old world and Antiquity (Vozilov 2009), and, hence, of the intelligentsia of Kievan Rus' (land of the Rus).

Intelligence in its philosophic meaning can be defined as the aesthetics of freedom of a subject's spirit and action for the sake of universal prosperity.

This concept of intelligence will be further based upon as a methodological means to analyze the statehood of Kievan Rus', as we believe that the dawn of the intelligentsia started long before the XIX century.

According to Academician D.S. Likhachev, in the IX-X centuries the Eastern Slavs aimed at uniting different tribes with the desire to escape from the oppressive loneliness among sparsely populated forests, swamps, and steppes. The fear of forlornness and threatening natural phenomena made people eager to unite (Likhachev 1988). The first Russian princes realized their social mission, which was a manifestation of their intelligence as an act emanating from the Slavic tribes' universal interests.

In 882 Prince Oleg marched to Kiev, implementing the idea to unite ancient lands. There

(C) Siberian Federal University. All rights reserved

* Corresponding author E-mail address: belovo@list.ru 
he fraudulently killed its Varangian warlords Askold and Dir and conquered the neighbors (the Drevlyans, the Severians, the Radimichs). The question about the price of achieving the goal may arise. We see the point in evaluating this act regarding the philosophy of that era. As for paganism, it did not consider the deception of the enemy to be a bad thing. As for the neighbours (the Drevlyans, for example), they only pressed Kiev and constantly attacked the Polans from thick forests. Other tribal peoples were laid under tribute by Oleg. It was less than that they paid to the Khazars. Still, the idea to unite the Russian land was worth it. It was inseparable from the idea of strengthening a princely power in the Slavic lands united around Kiev. Many Russian princes (from Oleg to, probably, Dmitry Donskoy) considered this idea to be the meaning of life, the service of truth.

Adoption of Christianity was the Russian princes' important philosophical act, particularly for the reason that the majority of the ruling class stubbornly resisted it and stuck to paganism. The first steps of Princess Olga to propagate Christianity in Russia, which, among other things, required her personal courage, were truly civil and intelligent ones. The adoption of Christianity in Russia was of a great universal significance. Olga also introduced new civilized habits to Kiev. As the church service could not do without church books, they started to introduce a new cultural stream in Russia. It was written language which favoured a human's mental growth (Tikhomirov 1991). A chronicler calls Olga "a forerunner of Christian land". Christianization of Rus' at Olga's grandson, Vladimir, made the country a completely equal member in the family of European nations. Awareness of equality caused awareness of history of mankind in Russia. Prominent representatives of the Orthodox Church later played a major role in the formation of national identity. Kievan Metropolitan's well- known "Sermon on Law and Grace" is worth being noted. Metropolitan Illarion of Kiev forecasts a general role of Rus' in Christian world. At the end of the X century "A Philosopher's Speech" was written. It was found in "Tale of Bygone Years", and namely in the article of the year 986, and was the first work of the Russian literature. It briefly tells the story of the world from its "creation" to the establishment of the universal church organization, Russian history being a part of it in future.

Alexander Nevsky was also a prominent person whose aim was to unite Rus', overcome intestine confrontation, opposing it to a different, hostile world, and save Russian spiritual culture. Opposing Birger's forces, he said, "We are only a few, and the enemy is strong, but God is not in force, but in truth. Go with your prince!" (Karamzin 1988). N.M. Karamzin mentions that Alexander Nevsky loved his homeland more than the honour of being the prince and despised personal danger no less than vanity. It is these qualities that apparently helped him to choose the most appropriate ways of behavior in relation to the German-Swedish invaders, with whom he relentlessly struggled, and a more flexible policy in respect of Mongolian khans posing a real danger to the Russian lands. The cornerstone of this policy was undoubtedly universal interests of the entire population of Russia but not the interests of a class.

Sacrificial behavior of Alexander Yaroslavich and his comrades-in-arms was strikingly different from morals of other feudal princes. Such dominant of behaviour, formulated by Alexander Nevsky, as altruistic patriotism determined the principles of the state ideology for centuries ahead. Traditions of alliance with the peoples of Asia based on national and religious tolerance, which were founded by the prince, attracted the neighbouring peoples to Russia up to the XIX century (Gumilev 1992). 
The Mongol expansion was a serious challenge for Russia. There were hardly a few Russian princes in the history of that period who proved capable of at least trying to revive the idea of Russian statehood. That is why, perhaps, the figure of Grand Prince Ivan Danilovich, later named Kalita, is so outstanding. He did his best to raise the status of Moscow which later became the capital of Russia. The chroniclers also mention that Ivan Kalita's accession to the throne to reign for 40 years led to peace and quietness in northern Rus'.

Whereas Ivan Kalita ensured peaceful labor in the fields for 40 years only the name of Dmitry Donskoy is associated with glory of the first winner over the Tatars. According to N.M. Karamzin, none of the descendants of Yaroslav the Great, except Monomakh and Alexander Nevsky, was loved by the people and court nobility as much as Dmitry. Dmitry deserved it for his generosity, love to Fatherland's glory, justice, and kindness. Brought up in danger and noise of war he had no knowledge of books but knew Russia and the art of ruling the state. The power of his mind and character earned the name of heroic eagle of state affairs given by his contemporaries. The writer's words of praise to Dmitry's virtues run: "Some people deserve praise in their teens, others in their middle or older age but Dmitry's whole life was for the good. Having taken the power from God, he with God's help glorified the Russian land, which flew into glory in the days of his reign" (Karamzin 1988).

Sergius of Radonezh is at equal worth with Dmitry Donskoy concerning his victory over the Tatars. He can probably be considered a kind of ideologist of the liberation movement against the Tatars. Just as archbishop Spyridon formerly blessed Alexander Nevsky for a fair fight with the Swedes, Sergius of Radonezh blessed Dmitry Donskoy and his army for the battle for Russia's freedom and glory, sprinkling Dmitry and his war chiefs with holy water and giving him two monks as his brothers in arms, who later earned their fame as Alexander Peresvet and Oslyabya [Ibid.].

Dwelling upon the origins of the Russian intelligentsia and analyzing the first Russian princes' behavior, aimed at the formation of Kievan Rus' in the process of awareness of its uniqueness and opposing it to the unknown countries, it is worth while mentioning the formation of a certain ideal of princely behavior. The records of the Chronicles focus upon this ideal and namely whole-hearted devotion to the country, the scorn of death in battle, democracy and Spartan lifestyle, and straightforwardness in dealing even with the enemy. This ideal existed before the adoption of Christianity but left a special mark on the stories about Christian ascetics after the adoption. The "Testament of Vladimir Monomakh" clearly shows the merger of the prince's pagan ideal of behaviour with Christian teachings. In Kievan Rus' a prince's important virtues were believed to be a scope of knowledge and mercy of the rich towards the poor and miserable.

The most characteristic representative of princely intelligentsia is Yaroslav the Wise. It is so due to his well-known enlightenment, love of the arts, and devoutness. His admonition to his children was the following: "You, children of the same father and mother, are not only called brothers. You must sincerely love each other. Be aware that civil strife, which is disastrous for you personally, will destroy the glory and greatness of the state founded by the blessed labors of our fathers and grandfathers. Peace and harmony will strengthen its power" (Idid.). Feeling his near death, Yaroslav was primarily concerned with serving a super goal of maintaining a united state.

Thus, we assume that such a socio-historical quality as intelligence is a phenomenon making 
the attempts to come to the knowledge of itself and build itself through its "otherness", that is to learn and build itself through God, statehood, spiritual tradition, and everything that really begins with the baptism of Rus', unites Rus' but opposes it to the whole world. In this case the roots of the intelligentsia really go back to the first Russian princes and spiritual pastors who had been creating the Russian state, Russian spiritual tradition in its open opposition to other world understanding, other worldview, and saved the spirit of Russian ethnos in the situation of constant pressure from other ethnic groups.

The role of Russian princes as the exponents of the Russian intelligentsia's nature is, most likely, over with the formation of a centralized state and the establishment of autocratic imperial power. Passing from generation to generation, intelligence forms in each of its representatives a desire to serve a super goal, truth and goodness, interests of universal prosperity. At certain stages of its development the intelligentsia comes into conflict with the official authorities representing the established worldview. As for the members of the intelligentsia, being a part of the nation capable of independent thinking, they form and have a new worldview. In this regard, we argue that at a certain stage the intelligentsia's functions pass from the Russian princes to the representatives of the Russian Orthodox Church.

\section{References}

1. Gumilev L.N. Ot Rusi k Rossii. Ocherki etnicheskoi istorii [From Russia to Russia. Issues on ethnic history]. Moscow, 1992. 336 p.

2. Karamzin N.M. Predaniia vekov [Legends of the centuries]. Moscow, 1988. 768 p.

3. Likhachev D.S. (1988). Kreshchenie Rusi i gosudarsto Rus' [The baptism of Rus' and the Russian state]. Novyi mir, 4, 249-258.

4. Tikhomirov M. (1991). Olga. Nash sovremennik, 6, 157-160.

5. Vozilov V.V. (2009). Historic sources of intelligentsia as a research problem. Intelligentsia and the World, 4, 3-17.

\section{Об истоках формирования интеллигенции как субъекта социального действия в России}

Г.В. Логунова

Иркутский государственный университет Россия, 664003, Иркутск, ул. Карла Маркса, 1

Рассмотрены вопросы формирования интеллигенциии как субъекта соииального действия. Автор пришел к выводу, что корни интеллигенции в России восходят к первым русским князьям, решавшим задачи создания российской государственности, духовной российской традици, служа сверхличной иеели, интересам общечеловеческого благоденствия.

Ключевые слова: интеллигенция, интеллигентность, Древнерусское государство, русские князья.

Научная спещиальность: 07.00.00 - исторические науки. 